ELORE (ISSN 1456-3010), vol. $16-2 / 2009$.

Julkaisija: Suomen Kansantietouden Tutkijain Seura ry.

[http://www.elore.fi/arkisto/2_09/kirjallisuus_kaarlenkaski_2_09.pdf]

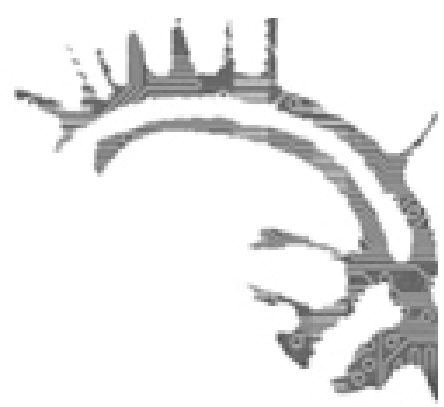

\title{
KIRJA-ARVIO:
}

\section{ROMANTTINEN ETNOGRAFIA MENNEESTÄ SAARISTOLAISELÄMÄSTÄ}

Suntala, Maria 2008: Onnellisia lebmiä ja viisaita ibmisiä. Elämää saariston luontaistaloudessa ja sen muntoksia. Hubmari: Karprint Oy. 304 sivua.

\section{Taija Kaarlenkaski}

Aatehistorioitsija ja ekofeministi Maria Suutala on kirjoittanut etnografisen tutkimuksen Ahvenanmaan saaristossa luontaistaloudessa eläneiden maailmankuvasta ja luontosuhteesta. Teoksen keskeisimpänä aineistona ovat 120 iäkkään ahvenanmaalaisen miehen ja naisen haastattelut. Näiden lisäksi Suutala on käyttänyt muutamia käsiinsä saamiaan muisti- ja päiväkirjoja sekä tutkimusaluetta koskevia historiikkeja ja lehtikirjoituksia. Kirja on tarkoitettu yleistajuiseksi esitykseksi, minkä takia tieteellisen tekstin tunnusmerkkejä, kuten lähdeviitteitä, on käytetty varsin niukasti. Suutalan tavoitteena on ollut elämänsä aikana luontaistaloudesta markkinatalouteen siirtyneiden ihmisten kokemusten ja luontosuhteen selvittäminen. Sisä-Suomen asukkaalle, jonka kokemukset Ahvenanmaasta rajoittuvat kenties Maarianhaminaan ja sen lähialueisiin, kirja avaa uudenlaisen näkökulman: saaristo näyttäytyy toisenlaisena kuin ruotsinlaivan kannelta katseltuna. Kirjasta on julkaistu myös hieman suppeampi ruotsinkielinen sisarteos (Suutala 2008). Molemmissa kirjoissa on runsas mustavalkoinen kuvitus, joka havainnollistaa saariston menneisyyttä.

\section{AATEHISTORIAA VAI ETNOGRAFIAA?}

Teoksen johdannossa Suutala sijoittaa tutkimuksensa aatehistorialliseen tutkimustraditioon: kohteena on niin sanotun tavallisen kansan maailmankuva. Aatehistoriallisen tutkimuksen valtavirrasta poiketen tärkeimmän aineiston muodostavat tutkijan itsensä 


\section{TAIJA KAARLENKASKI}

tekemät haastattelut, eivät kirjalliset lähteet. Aatehistoriaa vähemmän lukeneelle kirja näyttäytyykin etnografiana: pohdinnat "elämään osallistuvasta" ja "kokonaisvaltaisesta metodista" (s. 16) yhdistyvät lukijan mielessä vaivattomasti etnografiaan, vaikkei Suutala itse tätä termiä käytäkään. Sen sijaan hän pohtii tutkimuksensa suhdetta etnologiaan ja folkloristiikkaan ja kirjoittaa ulottavansa aatehistoriallisen tutkimuksen nyt alueelle, joka aiemmin on ollut kansanelämästä ja perinteestä kiinnostuneiden tutkijoiden hallussa. Suutalan mukaan aatehistoria pyrkii yhdistämään tavoitteen ymmärtää mennyttä sen omista lähtökohdista sekä tarpeen arvioida menneisyyttä nykyajan mittapuilla. Tällaista lähtökohtaa ei toki voi pitää vieraana kulttuurin- ja perinteentutkimuksellekaan. Suutalan voi toivottaa lämpimästi tervetulleeksi kulttuurintutkijoiden tyypillisesti hallitsemalle kentälle, mutta tästä teoksesta aatehistoriallisen näkökulman erityisyyttä on hieman vaikea hahmottaa.

Suutalan tutkimus perustuu pitkäjänteiseen kenttätyöhön ja haastatteluihin, jotka hän on tehnyt pääasiassa vuosina 2002-2004. Haastatteluissa hän ei ole käyttänyt nauhuria vaan on kirjoittanut muistiinpanot käsin. Tämä on vaatinut hänen mukaansa erityistä keskittymistä ja paneutumista haastattelutilanteeseen, varsinkin kun Ahvenanmaalla puhuttavien ruotsin murteiden ymmärtäminen vaatii harjaantumista. Suutala korostaa pyrkimystä haastattelutilanteen tasa-arvoisuuteen sekä haastattelijan ja haastateltavan kohtaamista subjekteina. Näihin ajatuksiin nauhurittomuus kieltämättä sopiikin: voihan nauhuri edustaa eräänlaista valta-asetelmaa tutkijan ja tutkittavan välillä. Lisäksi nauhurin käyttämättä jättäminen istuu tutkimuksessa muutenkin läpikulkevaan "luomuhenkeen". Haastattelujen tekemisen lisäksi Suutala on viettänyt pitkiäkin aikoja joidenkin informanttiensa luona sekä perehtynyt saariston elämään vuosikymmenien ajan, ensin turistina ja myöhemmin viettämällä siellä kokonaisia kesiä ja syksyjä. Tutkimuksesta huokuukin tekijänsä suoranainen rakkaus aihettaan kohtaan.

Aihepiirin läheisyyden takia Suutala on itse hyvin vahvasti läsnä tutkimuksessaan. Johdannossa hän mainitsee, että aatehistoriallisessa tutkimuksessa tulisi ottaa huomioon myös tutkijan henkilöhistorian ja maailmankuvan vaikutus tutkimukseen. Kootusti näitä taustoja tutkimuksesta ei kuitenkaan löydy, vaan kirjoittajan henkilökohtaisia näkemyksiä tulee esille pitkin matkaa ja joskus rivien väleissäkin. Suutala esimerkiksi kertoo omia vaikutelmiaan vierailuistaan joidenkin haastateltavien luo, kuvaileepa käyntinsä savusaunassakin. Ajoittain hän tunnustaa hyvinkin selkeästi ihailevansa luontaistaloudessa elämistä ja siihen liittyvää maailmankuvaa. Tällainen avoimuus on tutkimuksessa toki tärkeää, mutta omien asenteiden vaikutusta aineiston hankkimiseen ja analyysiin olisi voinut reflektoida huomattavasti enemmän. Aatehistorian lisäksi Suutalan tieteellinen tausta on feministisessä tutkimuksessa, ja hän kiinnittääkin erityistä huomiota naisten asemaan ja kokemuksiin. Vaikka sana ekofeminismi esiintyy kirjassa vain alussa Suutalaa esittelevässä infolaatikossa, tällaisen ajattelun voi nähdä kulkevan läpi koko teoksen. Aikaisemmassa kirjoituksessaan hän onkin luonnehtinut saariston vanhoja naisia oman sukupolvensa ekofeministeiksi, jotka ovat huolestuneita maailman tulevaisuudesta (Suutala 2006, 37).

Tutkimus keskittyy nimenomaan Ahvenanmaan saaristokuntiin, jotka ovat luonnonympäristöltään ja elinolosuhteiltaan varsin poikkeavia Ahvenanmaan "mantereeseen" nähden. Lähes kaikki haastatellut ovat kotoisin Kumlingesta, Föglöstä, Sottungasta, 
Kökarista ja Brändöstä, ja he ovat syntyneet vuosien 1901 ja 1943 välillä. Koska Suutala korostaa paitsi saariston eroja mantereeseen, myös saarten keskinäisiä eroja, kartta alueesta olisi ollut hyvä lisä havainnollistamaan tutkimusympäristöä sitä huonommin tuntevalle. Saarten luonnonolot vaikuttivat myös sukupuolten väliseen työnjakoon: karuimmilla saarilla, joilla ei ollut mahdollisuutta saada toimeentuloa karjanhoidosta, myös naiset osallistuivat miesten työnä pidettyyn kalastukseen. Haastatteluaineiston lisäksi tutkimuksessa tarkastellaan muutamia päivä- ja muistikirjoja sekä kökarilaisen opettajattaren 1930-1950-luvuilla julkaisemia lehtikirjoituksia. Kirjallisista aineistoista kiinnostavimmaksi osoittautuu föglöläisen naisen vuosina 1942-1973 kirjoittama päiväkirja, jossa kuvataan niin arkisia askareita kuin juhlahetkiäkin.

\section{SUHDE LUONTOON JA ELÄIMIIN}

Merkittävänä näkökulmana tutkimuksessa on luontaistalouden suhde kestävään kehitykseen: Suutala pohtii, missä määrin elämä omavaraistaloudessa oli ekologista ja miten markkinatalouteen siirtyminen on vaikuttanut luontosuhteeseen. Haastatelluista osa oli sitä mieltä, että elämä luontaistaloudessa oli parempaa ja onnellisempaa kuin nykyään, osa taas piti elämää luontaistaloudessa ankarana ja teknistä kehitystä elämänlaatua parantavana. Suutalan mukaan yllättävänkin suuri osa haastatelluista kuului ensimmäiseen ekologisesti tiedostavaan ja kulutuskriittiseen ryhmään. Toisaalta hän huomioi myös, että luontaistaloudella ei välttämättä ollut pelkästään positiivisia vaikutuksia ympäristölle: esimerkiksi Kökarissa liian suuri kotieläinten määrä luonnonvaroihin nähden johti ylilaidunnukseen ja puuston lähes täydelliseen häviämiseen ennen toista maailmansotaa. Pääosin luontaistaloudesta ja sen ympäristöystävällisyydestä annetaan kuitenkin hyvin myönteinen kuva. Luonnonantimia käytettiin vain sen verran kuin oli välttämätöntä, keinotekoisia torjunta-aineita ei käytetty eikä hajoamattomia jätteitä juuri syntynyt.

Folkloristin kiinnostuksen herättävät kertomukset luonnonhengistä ja enneunista. Kalastussaarten luonnonhenget varoittivat lähestyvästä myrskystä tai kertoivat, milloin oli tulossa hyvä kalansaalis. Lisäksi ne vartioivat myös ihmisten moraalia, joten haltija saattoi suuttua esimerkiksi metsästyksestä pitkäperjantaina. Suutala näkee luonnonhenkiuskon merkkinä ekologisesta viisaudesta: jos ihminen kohtelee luontoa hyvin, luontokin antaa hänelle apuaan ja antimiaan. Myös kasvilääkinnästä ja kansanomaisista sääennustusmenetelmistä on kirjassa jonkin verran kertomuksia. Sällä onkin saaristossa ollut merkittävä vaikutus elämään ja elannon hankintaan.

Ihmisen ja eläimen suhteista kiinnostuneelle kirjan kiinnostavinta antia on luku saaristolaisten suhteesta eläimiin. Suhtautuminen luonnonvaraisiin eläimiin määräytyi sen perusteella, mikä merkitys niillä oli ihmisen ravinnon saannille. Luonnoneläimet jakautuivat lähinnä hyödyllisiin pyyntieläimiin ja ihmisen kanssa samasta ravinnosta kilpaileviin vahinkoeläimiin. Vuosikymmenien kuluessa ja elinkeinojen muuttuessa esimerkiksi hylje on muuttunut tärkeästä saaliseläimestä vahinkoeläimeksi ainakin kalastajien silmissä, sillä ne voivat rikkoa verkkoja ja syödä saaliin pilalle. Luontaistalouden vihatuimpia eläimiä olivat merikotka ja käärme, mihin vaikuttivat myös 


\section{TAIJA KAARLENKASKI}

uskomukset ja tarinat. Kotkien kerrotaan käyneen jopa lasten kimppuun, ja käärmeistä taas kerrotaan monenlaisia uskomustarinoita jopa nukkuvan ihmisen suuhun luikertelevista käärmeistä.

Sen sijaan suhde kotieläimiin kuvataan lähes poikkeuksetta lämpimäksi. Lehmät ja hevoset olivat perheenjäseniä ja jopa ystäviä. Vaikka sekä haastateltavat että Suutala itse asettavat omavaraistalouden ja nykyisen tehokkaan eläintuotannon vastakohtapareiksi, ei läheinen suhde lehmiin ole tämänkään päivän karjanhoitajalle vieras. Tämä käy ilmi tutkimastani 2000-luvulla kerätystä lehmäaiheisen kirjoituskilpailun aineistosta. Nykyisin jopa 170 lehmän omistaja voi kertoa tuntevansa ne kaikki nimeltä (Harju 2007). Monet haastateltavista ovat korostaneet naisten läheisempää suhdetta eläimiin. Lehmien kerrotaan ymmärtäneen emäntiensä puhetta ja naiset pystyivät hallitsemaan myös arvaamattomia sonneja. Tämä erittäin mielenkiintoinen asia jää kuitenkin lähinnä toteamisen ja kuvailun asteelle; olisi ollut kiinnostavaa lukea ilmiötä koskevaa taustoitusta sekä tarkempaa analyysia naisten ja miesten eläinkäsitysten eroista. Vaikka Suutala mainitseekin kotieläinten joutuneen ulkosaaristossa elämään hyvin niukalla ravinnolla ja talvisin jopa nälkää nähden, saariston kotieläintalous näyttäytyy kokonaisuudessaan hyvin positiivisessa valossa.

\section{ENNEN KAIKKI OLI PAREMMIN?}

Läpi koko teoksen Suutala korostaa elämän luontaistaloudessa olleen yhteisöllistä ja modernisaation muuttaneen sen paitsi yksilökeskeisemmäksi myös yksinäisemmäksi. Tarkastellessaan föglöläisen naisen päiväkirjaa hän tulkitsee 1970-luvun muistiinpanoista puuttuvat hauskanpitomaininnat modernisaation ja ennen kaikkea television negatiiviseksi vaikutukseksi. Kylän yhteiset juhlat vaihtuivat koti-iltoihin television äärellä. Sen, että nainen ei enää kirjoita hauskanpidosta niin usein kuin aikaisemmin, voisi tulkita johtuvan myös ikääntymisestä ja mahdollisesta terveydentilan heikkenemisestä. Suutalan esittämissä päiväkirjaotteissa on myös hienovaraisia vihjauksia perheen sisäisiin ristiriitoihin, jotka todennäköisesti ovat vaikuttaneet kirjoittajan mielialaan. Kirjaa vaivaakin paikoittain suoranainen menneen romantisointi: Suutala toteaa jopa, että "[e]nnen ihmiset olivat sankareita" (s. 251). Vaikka omavaraistalous eittämättä oli ekologisempaa kuin nykyinen markkinatalous, voi pohtia, olivatko lehmät sen seurauksena välttämättä onnellisia ja ihmiset viisaita.

Suutalan tutkimus on persoonallinen puheenvuoro tällä hetkellä voimakkaassa nousussa olevaan ihmistieteelliseen luonto- ja eläinsuhteiden tutkimukseen. Taustalla on selvästi kirjoittajan aito huoli ympäristön tilasta ja tietyn elämäntavan häviämisestä. Lisäksi teos selvittää ansiokkaasti Ahvenanmaan saariston elämän vähemmän tunnettuja puolia: saarilla on tehty muutakin kuin kalastettu ja pystytetty juhannussalkoja. 
ROMANTTINEN ETNOGRAFIA MENNEESTÄ SAARISTOLAISELÄMÄSTÄ

\section{KirJallisuUs}

HARJU, JUKKA 2007: Mattilan maitotila Pälkäneellä on maaseudun tulevaisuus. Helsingin Sanomat 16.10.2007.

SUUTALA, MARIA 2006: Elävinä olentoina - luonnollisesti. - Naistutkimus - Kvinnoforskning 19(2).

-2008: Lyckliga kor och kloka människor. Mariehamn: PQR-kultur.

Filosofian maisteri Taija Kaarlenkaski on tutkijakoulutettava Kulttuuristen tulkintojen tutkijakoulussa ja perinteentutkimuksen jatko-opiskelija Joensuun yliopistossa. 